\title{
Contrasting influence of sea urchins on attached and drift macroalgae
}

\author{
Mathew A. Vanderklift ${ }^{1,2, *}$, Gary A. Kendrick ${ }^{1}$ \\ ${ }^{1}$ School of Plant Biology, The University of Western Australia, 35 Stirling Highway, Crawley, Western Australia 6009, Australia \\ ${ }^{2}$ Present address: CSIRO Marine Research, PO Box 5, Wembley, Western Australia 6913 and Centre for Ecosystem Management, \\ Edith Cowan University, 100 Joondalup Drive, Joondalup, Western Australia 6027, Australia
}

\begin{abstract}
Sea urchins can exert a profound influence on temperate reefs, but the extent of their influence also varies considerably among geographic locations. Here, we describe the influence of the sea urchin Heliocidaris erythrogramma on attached macroalgae and drift macrophytes at a subtidal rocky reef in south-western Australia. In one experiment, we manipulated the density of $H$. erythrogramma in fenced plots; in a second, we manipulated the presence and absence of $H$. erythrogramma in unfenced plots. The manipulation of $H$. erythrogramma density did not result in changes in attached macroalgal biomass, but the treatment with the highest density of sea urchins had a greater drift macrophyte biomass. When $H$. erythrogramma was removed from unfenced plots, a slightly higher macroalgal biomass was observed in the austral summer, but this difference was not present a few months later. However, the drift biomass was 4 times higher in plots where sea urchins were not removed. The dominant macrophyte species in the drift were scarce or absent from the assemblage growing attached to the reef, suggesting that much of the drift originated elsewhere, either in adjacent seagrass beds or on reefs hundreds of metres to kilometres away. There was a disproportionate retention of drift kelp Ecklonia radiata by $H$. erythrogramma. Based on these results, we propose that spatial subsidies in the form of drift macroalgae result in a weak influence of H. erythrogramma on attached macroalgae.
\end{abstract}

KEY WORDS: Detached reef algae - Ecklonia radiata - Grazing · Heliocidaris erythrogramma • Kelp $\cdot$ Sargassum $\cdot$ Spatial subsidy · Western Australia

Resale or republication not permitted without written consent of the publisher

\section{INTRODUCTION}

The feeding activities of sea urchins can exert a profound influence on the biomass and species composition of benthic macrophytes (see reviews by Lawrence 1975, Lawrence \& Sammarco 1982, Harrold \& Pearse 1987). In many temperate reef ecosystems, the influence of sea urchins is so great that they prevent the growth of all organisms other than encrusting algae. In some cases, they can remove dense stands of macroalgae over vast areas (e.g. Breen \& Mann 1976, Foreman 1977, Chapman 1981, Hagen 1995, Hjörleifsson et al. 1995).

In any particular area, the magnitude of the influence that sea urchins exert is partly a function of their abundance. Experiments in which sea urchin densities are manipulated usually yield a negative relationship between benthic macrophyte biomass and sea urchin density, although the relationship is not always linear (Sammarco 1982, Valentine \& Heck 1991, Andrew \& Underwood 1993, Prince 1995, Benedetti-Cecchi et al. 1998, Hill et al. 2003). Even low densities of sea urchins can influence the distribution and biomass of benthic macrophytes. For example, Palacín et al. (1998) showed that densities of Paracentrotus lividus of $<5 \mathrm{~m}^{-2}$ can reduce the cover of macroalgae.

The density of sea urchins is not the only important factor determining their effects on benthic macrophytes; feeding behaviour is also important. In some locations in California, Chile and South Africa, high 
densities of sea urchins exist, but exert no detectable influence on the biomass or species composition of the benthos. In these locations, the sea urchins do not actively graze, but instead feed on drift algae (Castilla \& Moreno 1982, Harris et al. 1984, Harrold \& Reed 1985, Contreras \& Castilla 1987, Dayton 1992, Day \& Branch 2002a). If drift becomes scarce, some species can change their feeding behaviour from a sedentary mode of feeding on drift to an active grazing mode. For example, in California, reductions in drift resulting from declines in the dominant macroalgae can lead to behavioural switches in which sea urchins leave shelter in search of food-with subsequent intensive grazing of kelp stands (Dean et al. 1984, Ebeling et al. 1985, Harrold \& Reed 1985, Harrold \& Pearse 1987).

In south-western Australia, intensively grazed areas of subtidal reef dominated by sea urchins have not been recorded. Generally, sea urchins are not abundant in this region (Fowler-Walker \& Connell 2002, Vanderklift \& Kendrick 2004), but on some reefs, densities of the purple sea urchin Heliocidaris erythrogramma average $8 \mathrm{~m}^{-2}$ and can exceed $40 \mathrm{~m}^{-2}$ (Vanderklift 2002, Vanderklift \& Kendrick 2004) — densities that are similar to those in intensively grazed areas elsewhere in the world (Kitching \& Ebling 1961, Mattison et al. 1977, Pearse \& Hines 1979, Andrew \& Choat 1982, Andrew 1993, Benedetti-Cecchi \& Cinelli 1995, Tuya et al. 2004). The apparent absence of intensively grazed areas in south-western Australia is interesting, because elsewhere in Australia $H$. erythrogramma can exert a strong influence on benthic macrophytes (Keesing 2002). For example, Wright \& Steinberg (2001) observed that grazing by aggregations of $H$. erythrogramma caused high mortality of macroalgae on a subtidal reef in New South Wales.

Intensively grazed areas might be absent in southwestern Australia because (1) sea urchins are grazing, but the relative influence of grazing is low; (2) sea urchins use drift as the main food source and do not graze; or (3) some combination of these. Here, we describe 2 experiments that address these alternative models. Specifically, we tested the null hypotheses that Heliocidaris erythrogramma has no influence on the biomass of either attached macroalgae or drift macrophytes retained on the reef. The first experiment tested for effects of different $H$. erythrogramma densities on attached macroalgae and drift macrophytes, using fenced plots. This experiment led us to the conclusion that $H$. erythrogramma exerted no significant influence on attached macrophytes at any of the natural densities. The second experiment tested for effects of natural sea urchin densities on the same variables, using unfenced plots in which the presence or absence of sea urchins was manipulated.

\section{MATERIALS AND METHODS}

Site description. The experiments were carried out on a subtidal reef at Mewstone, a rocky islet located approximately $8 \mathrm{~km}$ off the coast, west of Fremantle, Western Australia (3151' 07" S, $\left.115^{\circ} 42^{\prime} 48^{\prime \prime} \mathrm{W}\right)$. The reef is part of a chain of islands and high-relief limestone reefs formed from an aeolianite limestone ridge that runs parallel to the shore (Searle \& Semeniuk 1985). Experiments were set up on horizontal or gently sloping rock surfaces at depths of 4 to $7 \mathrm{~m}$. The fucoid brown algae Sargassum spp. was the dominant macroalgae in this habitat; other prominent species were the red algae Amphiroa anceps and Heterosiphonia crassipes, and the green alga Caulerpa obscura. The numerically dominant herbivore was the sea urchin Heliocidaris erythrogramma, which occurred in average densities of $8 \mathrm{~m}^{-2}$; most individuals were large (50 to $80 \mathrm{~mm}$ test diameter). The gastropods Turbo torquatus and Australium squamifera were also present, but in low densities $\left(<1 \mathrm{~m}^{-2}\right)$.

Expt 1: Manipulating Heliocidaris erythrogramma density. The first experiment tested the null hypothesis that the density of $H$. erythrogramma has no influence on the biomass of attached macroalgae or drift macrophytes at Mewstone. The experiment consisted of 6 treatments: 4 treatments in which densities of $H$. erythrogramma were manipulated $(0,6,12$ and 30 sea urchins per plot, corresponding to approximately 0,33 , 66 and $166 \%$ of the average natural densities at Mewstone), and 2 types of control ('Partial fence' and 'No fence'), in which sea urchin densities were not manipulated. The 2 types of control were included to estimate the potential effects of fencing and handling the sea urchins.

There were 4 replicate plots for each treatment. Plots were $1.5 \times 1.5 \mathrm{~m}\left(2.25 \mathrm{~m}^{2}\right)$, and were marked at the corners with steel pickets. Each plot was separated from the others by 1 to $2 \mathrm{~m}$, and plots of different treatments were spatially interspersed. Plots in which densities were manipulated were fenced around the entire perimeter with 60-ply black polyethylene mesh (approx. $5 \mathrm{~cm}$ stretched), attached top and bottom to a border of double-braided polyester rope $(10 \mathrm{~mm}$ diameter). The mesh was tied to steel pickets and attached to the rock. In the 'Partial fence' control, 3 sides of each plot were fenced, while the fourth was left open. In the second type of control (the 'No fence' treatment), plots were simply marked at the corners with steel pickets.

The experiment was started on 10 to 12 November 1999. Differences in densities or percentage covers of the dominant attached macroalgae were tested with 1-way ANOVA prior to setting up the experiment and were not found to be significantly different among 
plots (density of Sargassum spp.: $\mathrm{MS}=222.2, F_{5,18}=$ 0.95, p > 0.45; percentage covers of Heterosiphonia crassipes, Amphiroa anceps and Lobophora variegata, $F_{5,18}<1.0, \mathrm{p}>0.45$ in each case). Densities of Heliocidaris erythrogramma in each plot were recorded and then individual sea urchins were removed from all plots, except in the 'No fence' control. Sea urchins were then added to the 6,12 and 30-urchin plots at the required densities. $H$. erythrogramma were returned to each of the 'Partial fence' plots in the densities at which they were originally recorded - this procedure was included to control for possible effects of removing and repositioning urchins. Prior to manipulation, $H$. erythrogramma densities did not vary significantly among treatments (1-way ANOVA on $\log (x+1)$ transformed densities, $\mathrm{MS}=0.26, F_{5,18}=1.42, \mathrm{p}>0.25$ ), with an overall mean of $6.9 \mathrm{H}$. erythrogramma per plot $( \pm 9.2 \mathrm{SD})$. Sea urchin densities inside plots were checked approximately weekly, and adjusted if necessary. In the final week of April 2000, a severe storm (significant wave heights to $6 \mathrm{~m}$ ) destroyed 2 of the 30-urchin plots, with the damaged mesh scouring away much of the substratum: these plots were therefore excluded from analyses. The experiment was ended on 1 to 3 May 2000.

Data collection and analysis: At the end of the experiment, the densities and percentage covers of the dominant macroalgae were recorded. The macroalgae were then removed by hand or with a flat-bladed paint scraper from a $0.25 \mathrm{~m}^{2}$ quadrat and placed in bags, and were later sorted to species, dried in an oven for $48 \mathrm{~h}$ at $80^{\circ} \mathrm{C}$ and then weighed. Drift macroalgae and seagrass were collected by hand from the entire plot and placed in bags, and were later sorted to species, dried in an oven for $48 \mathrm{~h}$ at $80^{\circ} \mathrm{C}$ and then weighed. Differences in total biomass of attached macroalgae and drift among treatments were compared using ANOVA. Prior to all ANOVAs, heterogeneity of variances was tested using Cochran's $C$-test: if variances were significantly heterogeneous ( $p<0.05)$, data were square root transformed and re-tested. Transformation stabilised variances in all cases.

Expt 2: Effects of removing Heliocidaris erythrogramma. The second experiment tested the null hypothesis that removal of $H$. erythrogramma would yield no difference in the biomass of attached macroalgae and drift macroalgae. The experimental design consisted of 2 treatments: sea urchins removed $(-U)$ and sea urchins left undisturbed $(+\mathrm{U})$. We ran this design twice: we conducted the first run over an 11 mo period (June 2000 to May 2001), and the second over a 5 mo period (December 2000 to May 2001). At the beginning of each experimental run, 4 plots, each measuring $4 \times$ $4 \mathrm{~m}\left(16 \mathrm{~m}^{2}\right)$, were marked by hammering steel rods into the rock. Two plots were randomly assigned to the
$+\mathrm{U}$ treatment, the other 2 to the $-\mathrm{U}$ treatment; plots from different treatments and runs were spatially interspersed. Sea urchins were removed from the -U plots by hand. The plots were checked regularly (usually once a month) throughout both experiments.

At the beginning of each experimental run, the numbers of Heliocidaris erythrogramma were counted in 4 randomly positioned $1 \mathrm{~m}^{2}$ quadrats per plot. $H$. erythrogramma densities did not vary significantly among plots (untransformed densities: $\mathrm{MS}=150.1, F_{3,12}=1.05$, $\mathrm{p}>0.4$ for plots established in June; $\mathrm{MS}=27.7, F_{2,9}=$ $0.45, \mathrm{p}>0.6$ for plots established in December). Mean densities in each plot ranged from 3.2 to $17.0 \mathrm{~m}^{-2}$. Densities were successfully reduced in plots with no urchins $(-U)$, and few sea urchins moved into these plots during the experiment: At the end of the experiment, mean sea urchin densities in each plot ranged from 0 to $0.3 \mathrm{~m}^{-2}$ in the $-\mathrm{U}$ plots, and from 4.3 to $16.0 \mathrm{~m}^{-2}$ in the $+\mathrm{U}$ plots.

Data collection and analysis: Attached macroalgae were harvested from the plots on several occasions during both experimental runs. For plots established in June 2000, attached macroalgae were harvested on the first day of the experiment, and on 2 occasions approximately 6 and 11 mo later. For plots established in December 2000, attached macroalgae were harvested on the first day of the experiment, then approximately 5 mo after. Attached macroalgae were only harvested from the central $3 \times 3 \mathrm{~m}$ area of each plot: this central area was divided into a grid of 36 squares, each measuring $0.25 \mathrm{~m}^{2}$. Five squares were harvested each time; these were selected randomly without replacement to avoid harvesting the same area twice. All parts of the thallus were harvested, including holdfasts.

At the end of each experiment, drift algae and drift seagrass were collected by hand from three $1 \mathrm{~m}^{2}$ quadrats per plot. Drift was not collected during the experiment because sampling without replacement would have meant sampling the entire plot, and in the absence of knowledge about the dynamics of drift and sea urchin behaviour, we wished to avoid any changes in behaviour that removal of this potentially important food source might induce (as reported by Harrold \& Reed 1985).

At each sampling time, harvested attached algae, drift algae and drift seagrass were placed into bags and frozen until they were processed. They were sorted to species in the laboratory, dried at $80^{\circ} \mathrm{C}$ for at least $48 \mathrm{~h}$ and weighed.

The hypothesis that removal of Heliocidaris erythrogramma would lead to differences in attached macroalgal biomass was tested using a mixed-model ANOVA with the factors Treatment (fixed), Plot (random and nested in Treatment) and Time (fixed). We considered Time as fixed because sampling dates were 
specifically chosen to coincide with known growth peaks and periods of senescence of Sargassum spp. the dominant macroalgae (Kendrick \& Walker 1995). Data for each run of the experiment were analysed separately. Because the attached macroalgal biomass was similar between treatments at the beginning of the experiment, and was expected to change over its course if sea urchins were exerting an influence, the source of variation that was of most interest was the Treatment $\times$ Time interaction. For this reason, when the Plot(Treatment) $\times$ Time interaction was not significant at $p>0.25$, it was pooled into the Residual term to increase the power of the Treatment $\times$ Time test.

The hypothesis that removal of Heliocidaris erythrogramma would lead to differences in the biomass of drift macroalgae and seagrass was tested using nested ANOVA with the factors Treatment (fixed) and Plot (random and nested within Treatment). An initial model also included the factor Run (to test whether the 2 experimental runs yielded different results); however, this factor, and the Run $\times$ Treatment interaction were not significant $(p>0.20)$, and so plots from the 2 experimental runs were pooled.

Selection of drift by Heliocidaris erythrogramma. To explore the hypothesis that drift at Mewstone might not be representative of the assemblage growing attached to the reef, Chesson's (1983) index was used to analyse the drift data. This index is:

$$
\alpha_{i}=\frac{r_{i} / p_{i}}{\sum_{j=1}^{m} r_{j} / p_{j}}, i=1, \ldots, m
$$

where $r_{i}$ and $r_{j}$ are the proportion of biomass of species $i$ and $j$ in the drift, $p_{i}$ and $p_{j}$ are the proportion of biomass of species $i$ and $j$ growing on the reef, and $m$ is the total number of species (Chesson 1983).

For Expt 1, $\alpha_{i}$ values were calculated separately for each treatment (i.e. averaged over the replicate plots), using the biomass from the drift for $r_{i}$ and the biomass from the attached algae for $p_{i}$. For Expt 2, $\alpha_{i}$ values were calculated separately for each plot (i.e. averaged over the replicate quadrats at the end of the experiment), again using the biomass from the drift for $r_{i}$ and the biomass from the attached algae for $p_{i}$. For both experiments, if the algae were present in the drift in equal proportion to their biomass on the reef, then $\alpha_{i}=m^{-1}$. A value of $\alpha_{i}>m^{-1}$ indicates that the proportion of the biomass of a species in the drift was greater than expected from its proportion of the biomass of the attached assemblage; the $\alpha_{i}$ value itself does not indicate whether the discrepancy is statistically significant-we tested the hypotheses that $\alpha_{i}$ values varied systematically among treatments in Expt 1 with $Z$-tests, and in Expt 2 with Student's $t$-tests.

To test the hypothesis that Heliocidaris erythrogramma preferentially retains certain species of macroalgae, leading to their disproportionate representation in the drift, we collected drift from six $0.25 \mathrm{~m}^{2}$ quadrats in November 2001, and ten $0.25 \mathrm{~m}^{2}$ quadrats in July 2003. In each quadrat, drift was separated into items that were loose and items that were retained by sea urchins. If they do preferentially retain macroalgae, then those algae should be present mainly as drift retained by sea urchins - this was tested using 1-tailed paired $t$-tests.

\section{RESULTS}

\section{Expt 1: Manipulating Heliocidaris erythrogramma density}

There was no difference in total biomass of attached macroalgae among treatments at the end of the experiment $\left(\mathrm{MS}=529.9, F_{1,16}=1.58, \mathrm{p}>0.2\right.$; Fig. 1a). Unattached bottom drift collected from the plots at the end of the experiment mainly comprised large fragments of macroalgae and seagrass with associated epifauna
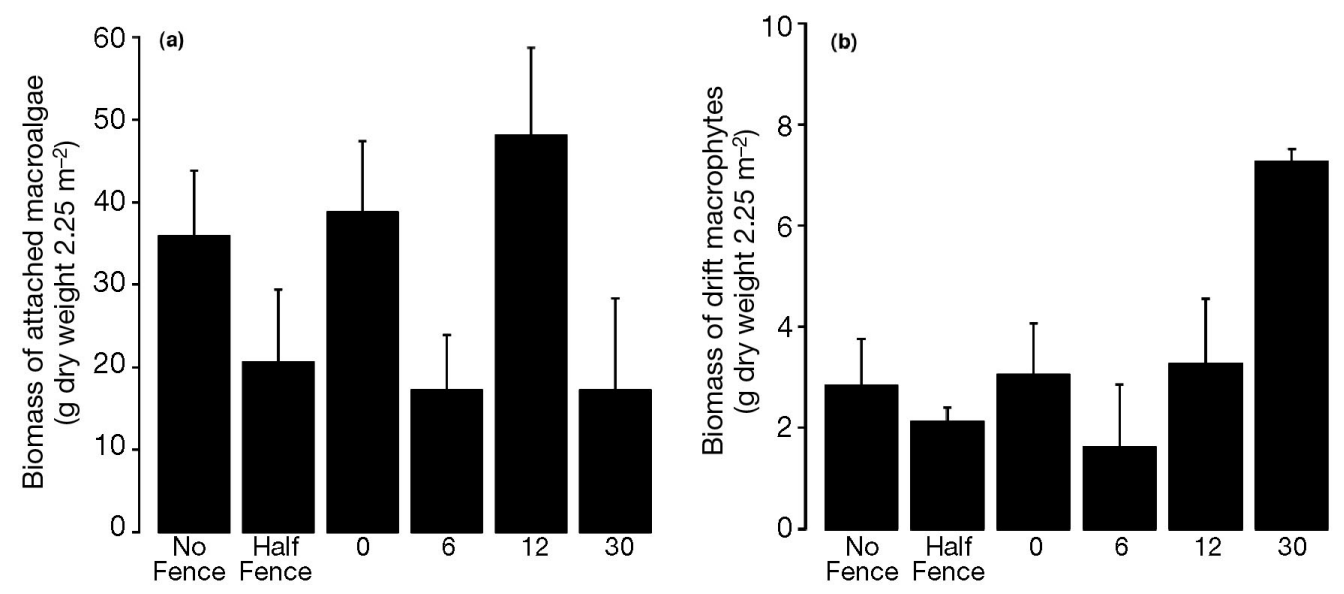

Fig. 1. Biomass of (a) attached macroalgae and (b) drift macrophytes for each treatment at the end of Expt 1 (mean + $\mathrm{SE}, \mathrm{n}=4$ except the 30-urchin treatment, for which $\mathrm{n}=2$ because of storm damage) 
(particularly the ascidian Pyura sp.). Drift biomass in the 30 urchin treatment was more than twice that of any other treatment (Fig. 1b), but the variance associated with the lower replication of that treatment resulted in a non-significant difference (1-way ANOVA on untransformed biomass, $\mathrm{MS}=9.52, F_{5,16}=$ $2.43, \mathrm{p}<0.1)$. Differences among treatments accounted for $30 \%$ of the variation in drift biomass, but differences were obscured by variability among plots, exacerbated by the lower number of replicates in the 30 -urchin treatment $(\mathrm{n}=2$, versus $\mathrm{n}=4$ in all other treatments).

Four species were over-represented in the drift collected from the 30-urchin plots compared to their relative biomass in the attached assemblage: the kelp Ecklonia radiata, the seagrasses Amphibolis spp. and Posidonia coriacea, and the ascidian Pyura sp. (a common epiphyte of Amphibolis spp.). The $\alpha_{i}$ values in the 30 -urchin treatment for these species was compared to those from all other treatments with $Z$-tests: $\alpha_{i}$ values of E. radiata and Pyura sp. were significantly higher $(p<0.01)$ than those of other treatments, while those of Amphibolis spp. and P. coriacea were not. This indicates that, while several species were present in the drift in quantities that were greater than predicted based on their presence in the assemblage growing on the reef, only E. radiata and Pyura sp. were likely to be influenced by the presence of high densities of Heliocidaris erythrogramma.

\section{Expt 2: Effects of removing Heliocidaris erythrogramma}

In the first experimental run (11 mo: June 2000 to May 2001), a significant difference in the total biomass of attached macroalgae was observed between plots with and without sea urchins in December 2000, but not in June 2000 or May 2001 (Treatment $\times$ Time interaction: Table 1; Fig. 2a). In December 2000, greater biomass of attached macroalgae occurred in the plots where Heliocidaris erythrogramma had been removed. There was also a significant plot effect, suggesting macroalgal biomass was spatially patchy (Table 1). Sargassum spp. comprised $>70 \%$ of the biomass in most plots at most times.

In the second run of the urchin removal experiment (5 mo: December 2000 to May 2001), the total biomass of attached macroalgae did not differ between treatments (Table 1; Fig. 2b). There was again significant temporal variation - biomass was significantly lower in May 2001 than December 2000 (Table 1) - but no significant interaction between treatment and time.

The biomass of drift macroalgae pooled from both experimental runs was significantly different between
Table 1. Results of ANOVA testing for differences in the combined biomass of attached algae from the experimental plots established in (a) June 2000 and (b) December 2000. In the ANOVA model, Treatment and Time were considered fixed factors, while Plot was considered a random factor. Bold indicates significance at $\mathrm{p} \leq 0.05$

\begin{tabular}{|c|c|c|c|c|}
\hline $\begin{array}{l}\text { (a) } 11 \text { mo experiment (J) } \\
\text { Transformation } \\
\text { Cochran's } C \text {-test }\end{array}$ & le 2 & $\begin{array}{l}\text { 00-May } 2 \\
\quad X^{0.5} \\
=0.24 \cdot \mathrm{p}>\end{array}$ & $\begin{array}{l}001) \\
0.05\end{array}$ & \\
\hline Source of variation & $\mathrm{df}$ & MS & $F$ & $\mathrm{p}$ \\
\hline Treatment & 1 & 3.09 & 0.37 & 0.605 \\
\hline Plot (Treatment) & 2 & 8.37 & $3.65^{\mathrm{a}}$ & 0.033 \\
\hline Time & 2 & 125.4 & $54.67^{\mathrm{a}}$ & $<0.001$ \\
\hline Treatment $\times$ Time & 2 & 7.64 & $3.33^{\mathrm{a}}$ & 0.043 \\
\hline Plot $($ Treatment $) \times$ Time & 4 & 1.36 & 0.57 & 0.682 \\
\hline Residual & 48 & 2.37 & & \\
\hline \multicolumn{5}{|c|}{ (b) 5 mo experiment (December 2000-May 2001) } \\
\hline Transformation & \multirow{2}{*}{\multicolumn{4}{|c|}{$C=0.34, \mathrm{p}>0.05$}} \\
\hline Cochran's $C$-test & & & & \\
\hline Source of variation & df & MS & $F$ & $\mathrm{p}$ \\
\hline Treatment & 1 & 282.9 & 1.01 & 0.421 \\
\hline Plot (Treatment) & 2 & 280.2 & $0.66^{\mathrm{a}}$ & 0.524 \\
\hline Time & 1 & 11520.0 & $27.1^{\mathrm{a}}$ & $<0.001$ \\
\hline Treatment $\times$ Time & 1 & 1.0 & $0.002^{\mathrm{a}}$ & 0.962 \\
\hline Plot (Treatment) $\times$ Time & 2 & 1.8 & 0.004 & 0.996 \\
\hline Residual & 32 & 451.5 & & \\
\hline \multicolumn{5}{|c|}{$\begin{array}{l}{ }^{\text {a }} \text { Denominator for the } F \text {-ratio was pooled MS of the Plo } \\
\text { (Treatment) } \times \text { Time interaction and the Residual }\end{array}$} \\
\hline
\end{tabular}

plots with and without Heliocidaris erythrogramma (Fig. 3a: $\mathrm{MS}=1.67, F_{1,6}=6.85, \mathrm{p}<0.05$ ). Plots with sea urchins had, on average, $4 \times$ the biomass of drift macroalgae than plots without (Fig. 3a). In contrast, there was no significant difference in the biomass of drift seagrass between plots with and without sea urchins (Fig. $3 \mathrm{~b}$ : $\mathrm{MS}=0.04, F_{1,6}=0.17, \mathrm{p}>0.6$ ).

Eight species ( 2 of seagrasses and 6 of macroalgae) were present as drift in at least 1 of the 8 plots in greater biomass than expected based on their presence in the attached assemblage (4 plots for each of the $+U$ and $-U$ treatments: Table 2). The most dominant species in the drift were not dominant in the assemblage growing on the reef, and some did not occur there at all (Fig. 4). To test the hypothesis that the presence of Heliocidaris erythrogramma influenced the proportion of each species present as drift, the $\alpha_{i}$ values for the 2 treatments (i.e. $+\mathrm{U}$ and $-\mathrm{U}$ ) were compared using a Student's $t$-test. The kelp Ecklonia radiata and the red alga Lenormandia marginata yielded significantly higher $\alpha_{i}$ values in $+U$ plots, indicating that their abundance in the drift was influenced by the presence of $H$. erythrogramma (Table 2). 

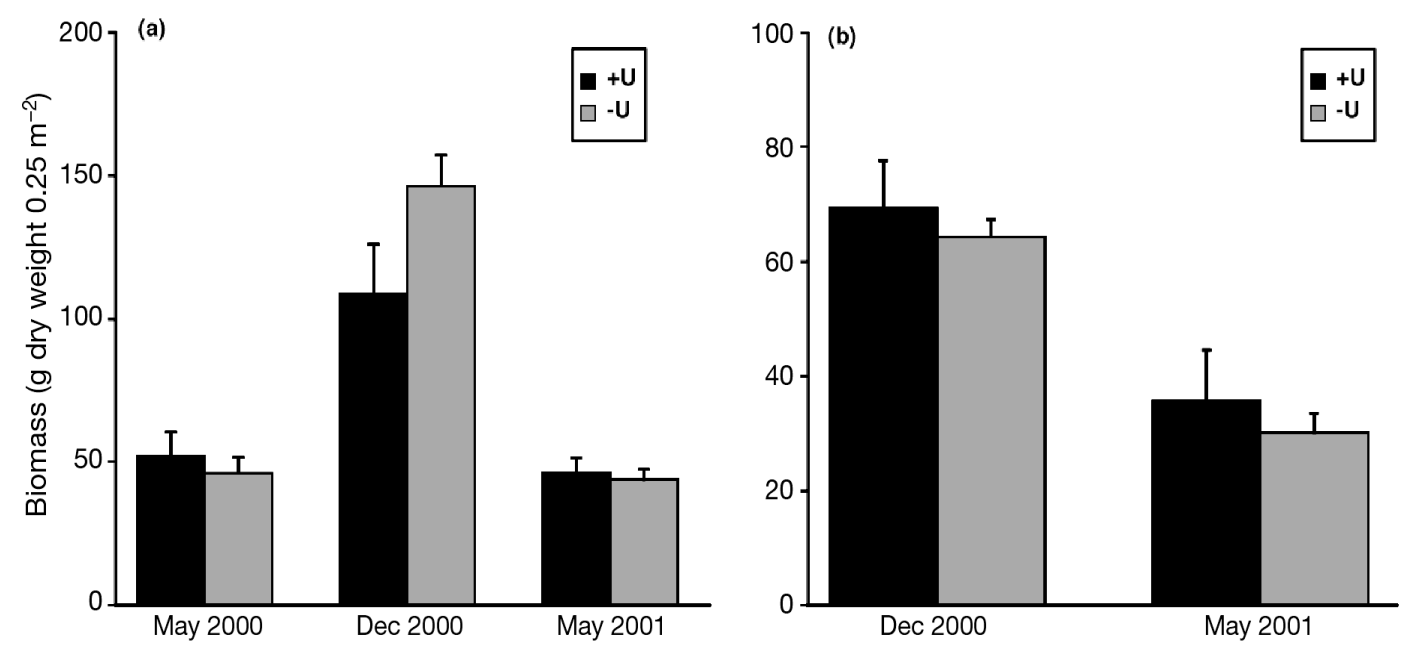

Fig. 2. Biomass of total attached algae harvested from $0.25 \mathrm{~m}^{2}$ quadrats within plots with (+U) and without (-U) sea urchins $($ mean $+\mathrm{SE}, \mathrm{n}=10)$. Experiment started in (a) June 2000, and (b) December 2000
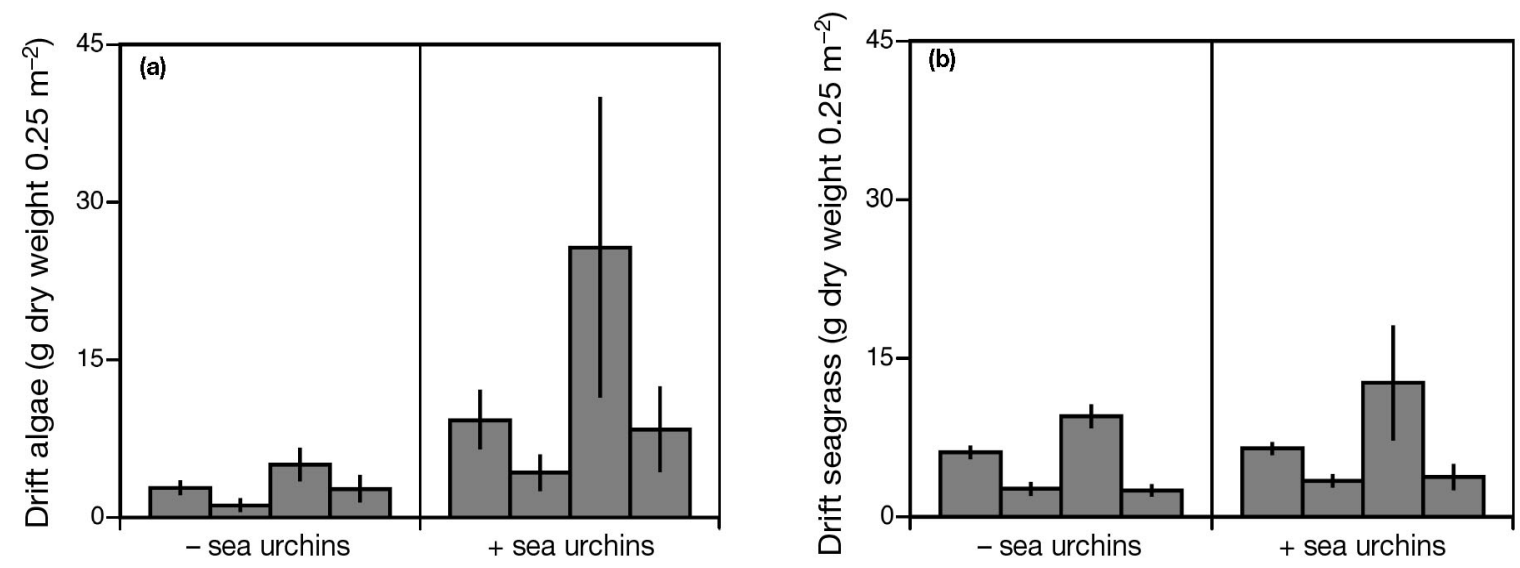

Fig. 3. Biomass of (a) drift algae and (b) drift seagrass (mean $\pm \mathrm{SE}, \mathrm{n}=3$ ) in plots with and without sea urchins

These results suggest that Heliocidaris erythrogramma preferentially retained certain species of macroalgae, leading to their disproportionate representation in the drift. When samples were taken (in November 2001 and July 2003), Ecklonia radiata, Amphibolis spp. and Posidonia coriacea were the main components of the drift. E. radiata was mainly present as drift retained by sea urchins, and rarely present as loose-lying drift; the difference in biomass was significant (November 2001: $t_{5}=2.22, \mathrm{p}<0.04$; July 2003: $t_{9}=2.03, \mathrm{p}<0.05$ ). Amphibolis spp. and P. coriacea were present as looselying drift and as drift retained by sea urchins; there were no differences in biomass in November 2001, while the biomass was greater as loose-lying drift in July 2003. The results further support the idea that $H$. erythrogramma preferentially selects and retains $E$. radiata.

\section{DISCUSSION}

\section{Limited influence on attached macroalgae}

Of the alternative models outlined in the introduction, there was strong evidence to support the hypothesis that Heliocidaris erythrogramma uses drift as its main food source, but there was only weak evidence to support the hypothesis that $H$. erythrogramma grazes attached macroalgae. We propose that, at Mewstone, $H$. erythrogramma is 'subsidised' by drift from elsewhere and that this results in weak interactions with attached macroalgae, and a weak short-term influence on the assemblage of macroalgae.

No differences in the biomass of attached macroalgae were detected in the experimental manipulation of Heliocidaris erythrogramma density. However, in De- 
Table 2. Species that were present as drift in the removal experiment in greater quantities than expected based on the proportion of the total biomass growing attached to the reef. Data were pooled from both experimental runs, so $\mathrm{n}=4$ for each treatment. p: results of Student's $t$-test of differences between the mean $\alpha$ of urchin-removal and control plots. Bold indicates significance at $\mathrm{p} \leq 0.05$

\begin{tabular}{|c|c|c|c|c|c|}
\hline \multirow[t]{2}{*}{ Drift species } & \multicolumn{2}{|c|}{ No. of plots in which $\alpha_{i}>m^{-1}$} & \multicolumn{2}{|c|}{ Mean $\alpha_{i}$} & \multirow[t]{2}{*}{$\mathrm{p}$} \\
\hline & $+\mathrm{U}$ & $-\mathrm{U}$ & $+\mathrm{U}$ & $-\mathrm{U}$ & \\
\hline \multicolumn{6}{|l|}{ Seagrass } \\
\hline Posidonia coriacea & 4 & 4 & 0.16 & 0.25 & 0.113 \\
\hline Amphibolis spp. & 3 & 4 & 0.22 & 0.40 & 0.095 \\
\hline \multicolumn{6}{|l|}{ Macroalgae } \\
\hline Ecklonia radiata & 4 & 0 & 0.13 & 0.05 & 0.018 \\
\hline Plocamium sp. & 3 & 3 & 0.17 & 0.10 & 0.163 \\
\hline Lenormandia marginata & 3 & 0 & 0.12 & 0.04 & 0.039 \\
\hline Jeannerettia pedicillata & 2 & 1 & 0.05 & 0.06 & 0.788 \\
\hline Dictyomenia sonderi & 2 & 0 & 0.06 & 0.03 & 0.299 \\
\hline Dictyomenia australis & 0 & 1 & 0.00 & 0.02 & 0.356 \\
\hline
\end{tabular}

and even lower, densities of comparably sized sea urchins have been shown to influence the biomass and species composition of benthos on temperate reefs elsewhere: examples are Strongylocentrotus fransicanus and $S$. purpuratus in California (Mattison et al. 1977, Pearse \& Hines 1979); Paracentrotus lividus and Arbacia lixula in Europe (Kitching \& Ebling 1961, Benedetti-Cecchi \& Cinelli 1995); Evechinus chloroticus in New Zealand (Andrew \& Choat 1982, Shears \& Babcock 2003); Centrostephanus rodgersii in eastern Australia (Andrew \& Underwood 1989, Andrew 1993); and Diadema antillarum in the Canary Islands (Tuya et al. 2004). Even naturally low densities of $P$. lividus $\left(<5 \mathrm{~m}^{-2}\right)$

cember 2000, a small difference in attached macroalgal biomass was present between plots with sea urchins and those where they were excluded for 6 mo. At that time, macroalgal biomass in plots with sea urchins was $75 \%$ of that in plots without. This is consistent with a small amount of grazing, but may also be simply due to pre-emption of space by $H$. erythrogramma, because at the densities and sizes observed at Mewstone, they occupy up to $20 \%$ of the space available in some areas. The difference was only detected at the beginning of the austral summer, when Sargassum spp. reach their annual growth peak (Kendrick \& Walker 1995).

At Mewstone, Heliocidaris erythrogramma densities average $8 \mathrm{~m}^{-2}$, although they can exceed $40 \mathrm{~m}^{-2}$ (Vanderklift 2002, Vanderklift \& Kendrick 2004). Similar, can influence the abundance of macroalgae (Palacín et al. 1998). Experimental reductions of sea urchin densities have also shown that sea urchins can exert a major influence at lower densities (Andrew \& Underwood 1993, Benedetti-Cecchi et al. 1998).

The minor influence of Heliocidaris erythrogramma on attached macroalgae at Mewstone contrasts with the many studies that show strong influence of sea urchins, but is consistent with studies of Strongylocentrotus spp. in California (Harrold \& Reed 1985), of Loxechinus albus in Chile (Castilla \& Moreno 1982), and of Parechinus angulosus in South Africa (Day \& Branch 2002b). Day \& Branch (2002b) reported that removal of $P$. angulosus from reefs in South Africa had no effect on foliose algal cover, or on the number of holdfasts or

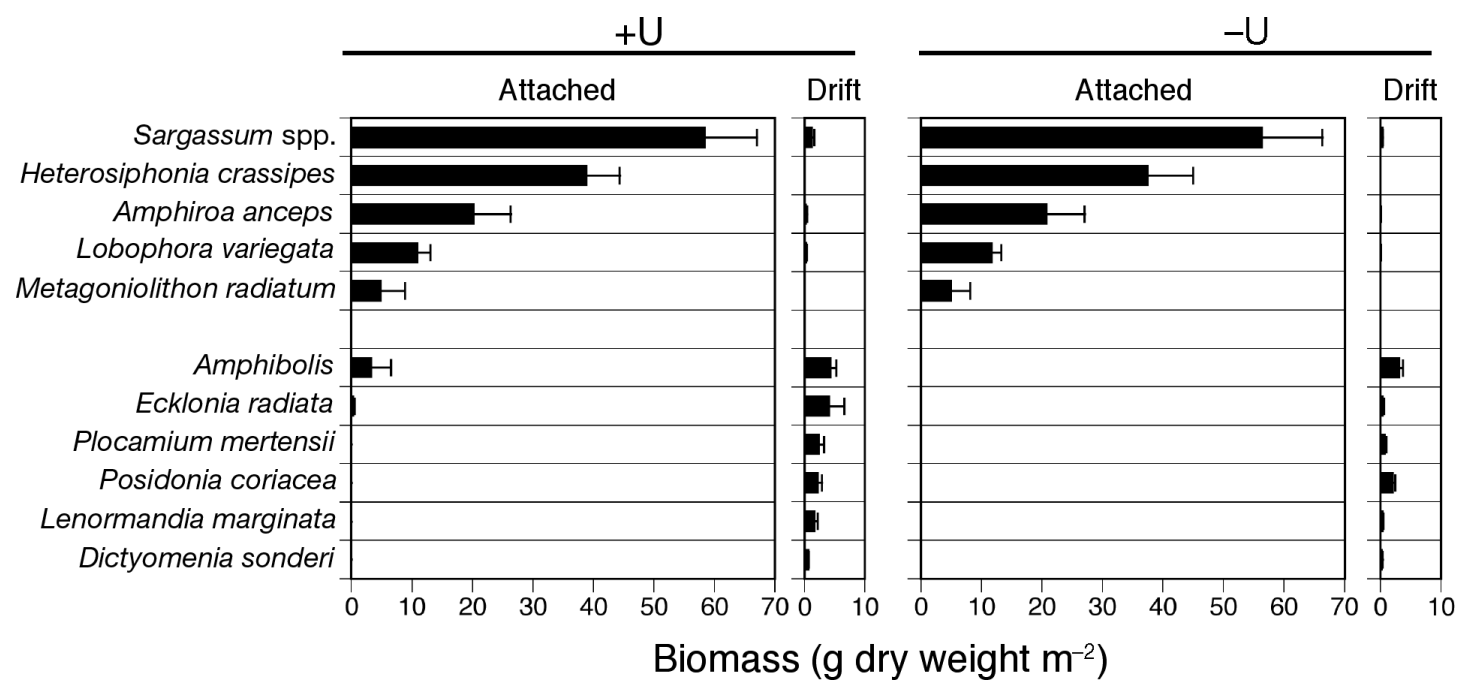

Fig. 4. Biomass of attached and drift algae and seagrass (mean $+\mathrm{SE}, \mathrm{n}=12$ for drift, $\mathrm{n}=20$ for attached) at the end of the removal experiment. Data were pooled from the 2 experimental runs. The 5 species with the highest biomasses when attached and as drift are shown. Note that the attached species were converted to units of $g$ dry weight $\mathrm{m}^{-2}$ for the purposes of comparison 
sporelings of the kelp Ecklonia maxima. In their study, there was a decline in drift kelp biomass when sea urchins were removed, suggesting that $P$. angulosus retains and feeds on drift kelp (Day \& Branch 2002a,b). In Italy, Bulleri et al. (1999) found that removal of Paracentrotus lividus had little effect on the assemblage of attached algae, and suggested that this was because $P$. lividus remained in crevices and fed on drift algae. In contrast, their removals of Arbacia lixula yielded a strong effect on the attached algae.

\section{Large influence on drift}

The clearest outcome of our experiments was the increase in drift algal biomass with the presence of Heliocidaris erythrogramma. This positive effect was due to the 'trapping' behaviour of the sea urchins: they were observed to hold drift algae with their tube feet, preventing it from being removed by water movement.

Drift biomass was dominated by the seagrasses Amphibolis spp. and Posidonia coriacea, and the laminarian kelp Ecklonia radiata (Fig. 4). None of these species was abundant in the assemblage growing attached to the reef. There was evidence that Heliocidaris erythrogramma preferentially retained some species of drift algae - in particular, the biomass of drift E. radiata was higher in plots with sea urchins, and was mainly present as retained drift. The high proportion of drift $E$. radiata was much greater than that found growing on the reef. E. radiata ranked 35 th in biomass of attached macroalgae, but 1st in biomass of drift macroalgae (although the biomass of drifting fragments of the seagrass Amphibolis spp. was greater). Other sea urchins have been shown to have feeding preferences for laminarian algae (e.g. Vadas 1977, Larson et al. 1980, Schiel 1982, Himmelman 1984, Himmelman \& Nédélec 1990), and it is possible that trapping and consumption of drift E. radiata by $H$. erythrogramma at Mewstone might occur because it is a preferred food. However, there are other possible explanations: for example, E. radiata is a large, heavy alga that drifts along the bottom, potentially providing more chances for capture by drift-feeding organisms.

\section{Spatial subsidy by drift}

Consumption of drift is a common mode of feeding by echinoids (Lawrence 1975). In some instances it has been invoked as a possible reason for an unexpected lack of effects of sea urchins on benthos (Bulleri et al. 1999, McClanahan 1999, Day \& Branch 2002a). However, the amount of drift has rarely been quantified. In several North American studies in which drift was quantified, drift algae were more abundant inside kelp stands than outside (Harrold \& Reed 1985, Konar \& Estes 2003), and this probably enabled Strongylocentrotus spp. to remain in shelters instead of foraging in the open (Lowry \& Pearse 1973, Harris et al. 1984, Harrold \& Reed 1985).

Results from studies of kelp stands in California, South Africa and Alaska indicate that the main species in the drift were similar to those growing in the immediate vicinity. This suggests that sea urchins in those studies fed on autochthonous drift - that is, drift generated within the stand that they lived in. This does not seem to be the case at Mewstone. The greatest drift macroalgal biomass was recorded for the kelp Ecklonia radiata (in May and November), and the red algae Plocamium sp. and Lenormandia marginata (in May only). None of these species was a dominant component of the assemblage of attached macroalgae at Mewstone. E. radiata is abundant at reefs elsewhere on the south-western Australian coast (Wernberg et al. 2003), but is restricted to a few small stands at Mewstone. The drift $E$. radiata at Mewstone has, therefore, probably originated from other reefs - the nearest reefs with abundant $E$. radiata are at least several hundred metres away, and these are the nearest likely source of the drift. Kirkman \& Kendrick (1997) found that tagged E. radiata drifted for $>2 \mathrm{~km}$, so drift $E$. radiata at Mewstone potentially originated even further away. Plocamium sp. and L. marginata did not occur in experimental plots except as drift; at Mewstone both are more commonly found as epiphytes of larger macroalgae and the seagrass Amphibolis griffithii, which grows in large meadows around Mewstone.

We therefore suggest that the main food for Heliocidaris erythrogramma at Mewstone is allochthonous drift, probably originating from adjacent seagrass beds and from reefs further offshore. Depending on the source of the drift, this implies trophic linkages encompassing spatial extents from tens of metres to several kilometres. The underlying causes of differences in the behaviour of $H$. erythrogramma in our study area, where it feeds on drift macrophytes and exerts little influence on attached macroalgae, and other localities in Australia, where it can exert a strong influence on attached macroalgae (Wright \& Steinberg 2001, Keesing 2002) warrant further investigation in view of their potential to yield profound differences in community structure.

Acknowledgements. We would like to thank all of the hardy divers who volunteered to help, for without them this work would not have been possible: the efforts of A. J. Smit, T. Wernberg, M. Westera, E. Harvey and M. Polifrone are particularly worth highlighting. M.A.V. was supported by an Australian Postgraduate Award. Comments by G. M. Branch, N. Goldberg, J. McDonald, B. Toohey and T. Wernberg improved the manuscript. 


\section{LITERATURE CITED}

Andrew NL (1993) Spatial heterogeneity, sea urchin grazing, and habitat structure on reefs in temperate Australia. Ecology 74:292-302

Andrew NL, Choat JH (1982) The influence of predation and conspecific adults on the abundance of juvenile Evechinus chloroticus (Echinoidea: Echinometridae). Oecologia 54: 80-87

Andrew NL, Underwood AJ (1989) Patterns of abundance of the sea urchin Centrostephanus rodgersii (Agassiz) on the central coast of New South Wales, Australia. J Exp Mar Biol Ecol 131:61-80

Andrew NL, Underwood AJ (1993) Density-dependent foraging in the sea urchin Centrostephanus rodgersii on shallow subtidal reefs in New South Wales, Australia. Mar Ecol Prog Ser 99:89-98

Benedetti-Cecchi L, Cinelli F (1995) Habitat heterogeneity, sea urchin grazing and the distribution of algae in littoral rock pools on the west coast of Italy (western Mediterranean). Mar Ecol Prog Ser 126:203-212

Benedetti-Cecchi L, Bulleri F, Cinelli F (1998) Density dependant foraging of sea urchins in shallow subtidal reefs on the west coast of Italy (western Mediterranean). Mar Ecol Prog Ser 163:203-211

Breen PA, Mann KH (1976) Destructive grazing of kelp by sea urchins in eastern Canada. J Fish Res Board Can 33: 1278-1283

Bulleri F, Benedetti-Cecchi L, Cinelli F (1999) Grazing by the sea urchins Arbacia lixula L. and Paracentrotus lividus Lam. in the Northwest Mediterranean. J Exp Mar Biol Ecol 241:81-95

Castilla JC, Moreno CA (1982) Sea urchins and Macrocystis pyrifera: experimental test of their ecological relations in southern Chile. In: Lawrence JM (ed) International echinoderms conference, Tampa Bay. AA Balkema, Rotterdam, p 257-263

Chapman ARO (1981) Stability of sea urchin dominated barren grounds following destructive grazing of kelp in St. Margaret's Bay, eastern Canada. Mar Biol 62:307-311

Chesson J (1983) The estimation and analysis of preference and its relationship to foraging models. Ecology 64: 1297-1304

Contreras S, Castilla JC (1987) Feeding behaviour and morphological adaptations in two sympatric sea urchin species in central Chile. Mar Ecol Prog Ser 38:217-224

Day E, Branch GM (2002a) Influences of the sea urchin Parechinus angulosus (Leske) on the feeding behaviour and activity rhythms of juveniles of the South African abalone Haliotis midae Linn. J Exp Mar Biol Ecol 276:1-17

Day E, Branch GM (2002b) Effects of sea urchins (Parechinus angulosus) on recruits and juveniles of abalone (Haliotis midae). Ecol Monogr 72:133-149

Dayton PK (1992) Community landscape: scale and stability in hard bottom marine communities. In: Giller PS, Hildrew AG, Raffaelli DG (eds) Aquatic ecology: scale, pattern and process. Blackwell Scientific Publications, Oxford, p 289-332

Dean TA, Schroeter SC, Dixon JD (1984) Effects of grazing by two species of sea urchins (Strongylocentrotus franciscanus and Lytechinus anamesus) on recruitment and survival of two species of kelp (Macrocystis pyrifera and Pterygophora californica). Mar Biol 78:301-313

Ebeling AW, Laur DR, Rowley RJ (1985) Severe storm disturbances and reversal of community structures in a southern Californian kelp forest. Mar Biol 84:287-294

Foreman RE (1977) Benthic community modification and recovery following intensive grazing by Strongylocentrotus droebachiensis. Helgol Wiss Meeresunters 30:468-484 Fowler-Walker MJ, Connell SD (2002) Opposing states of subtidal habitat across temperate Australia: consistency and predictability in kelp canopy-benthic associations. Mar Ecol Prog Ser 240:49-56

Hagen NT (1995) Recurrent destructive grazing of successionally immature kelp forests by green sea urchins in Vestfjorden, Northern Norway. Mar Ecol Prog Ser 123: 95-106

Harris LG, Ebeling AW, Laur DR, Rowley RJ (1984) Community recovery after storm damage: a case of facilitation in primary succession. Science 224:1336-1338

Harrold C, Pearse JS (1987) The ecological role of echinoderms in kelp forests. In: Jangoux M, Lawrence JM (eds) Echinoderm studies, Vol 2. AA Balkema, Rotterdam, p 137-233

Harrold C, Reed DC (1985) Food availability, sea urchin grazing, and kelp forest community structure. Ecology 1985: 1160-1169

Hill NA, Blount C, Poore AGB, Worthington D, Steinberg PD (2003) Grazing effects of the sea urchin Centrostephanus rodgersii in two contrasting rocky reef habitats: effects of urchin density and its implication for the fishery. Mar Freshw Res 54:691-700

Himmelman JH (1984) Urchin feeding and macroalgal distribution in Newfoundland, eastern Canada. Nat Can 111: $337-348$

Himmelman JH, Nédélec H (1990) Urchin foraging and algal survival strategies in intensely grazed communities in eastern Canada. Can J Fish Aquat Sci 47:1011-1026

Hjörleifsson E, Kaasa Ö, Gunnarsson K (1995) Grazing of kelp by green sea urchin in Eyjafjördur, North Iceland. In: Skjoldal HR, Hopkins C, Erikstad KE, Leinaas HP (eds) Ecology of fjords and coastal waters. Elsevier, Amsterdam, p 593-597

Keesing JK (2002) The ecology of Heliocidaris erythrogramma. In: Lawrence JM (ed) Edible sea urchins: biology and ecology. Elsevier, Amsterdam, p 261-270

Kendrick GA, Walker DI (1995) Dispersal of propagules of Sargassum spp. (Sargassaceae: Phaeophyta): Observations of local patterns of dispersal and consequences for recruitment and population structure. J Exp Mar Biol Ecol 192:273-288

Kirkman H, Kendrick GA (1997) Ecological significance and commercial harvesting of drifting and beach-cast macroalgae and seagrasses in Australia: a review. J Appl Phycol 9:311-326

Kitching JA, Ebling FJ (1961) The ecology of Lough Ine. XI. The control of algae by Paracentrotus lividus (Echinoidea). J Anim Ecol 30:373-383

Konar B, Estes JA (2003) The stability of boundary regions between kelp beds and deforested areas. Ecology 84: 174-185

Larson BR, Vadas RL, Keser M (1980) Feeding and nutritional ecology of the sea urchin Strongylocentrotus drobachiensis in Maine, USA. Mar Biol 59:49-62

Lawrence JM (1975) On the relationship between marine plants and sea urchins. Oceanogr Mar Biol Annu Rev 13: 213-286

Lawrence JM, Sammarco PW (1982) Effects of feeding on the environment: Echinoidea. In: Jangoux M, Lawrence JM (eds) Echinoderm nutrition. AA Balkema, Rotterdam, p 499-519

Lowry LF, Pearse JS (1973) Abalones and sea urchins in an area inhabited by sea otters. Mar Biol 23:213-219

Mattison JE, Trent JD, Shanks AL, Akin TB, Pearse JS (1977) 
Movement and feeding activity of red sea urchins (Strongylocentrotus franciscanus) adjacent to a kelp forest. Mar Biol 39:25-30

McClanahan TR (1999) Predation and control of the sea urchin Echinometra viridis and fleshy algae in the patch reefs of Glovers Reef, Belize. Ecosystems 2:511-523

Palacín C, Giribet G, Carner S, Dantart L, Turon X (1998) Low densities of sea urchins influence the structure of algal assemblages in the western Mediterranean. J Sea Res 39: 281-290

Pearse JS, Hines AH (1979) Expansion of a central California kelp forest following the mass mortality of sea urchins. Mar Biol 51:83-91

Prince J (1995) Limited effects of the sea urchin Echinometra mathaei (de Blainville) on the recruitment of benthic algae and macroinvertebrates into intertidal rock platforms at Rottnest Island, Western Australia. J Exp Mar Biol Ecol 186:237-258

Sammarco PW (1982) Effects of grazing by Diadema antillarum Phillipi (Echinodermata: Echinoidea) on algal diversity and community structure. J Exp Mar Biol Ecol 65: 83-105

Schiel DR (1982) Selective feeding by the echinoid, Evechinus chloroticus, and the removal of plants from subtidal algal stands in northern New Zealand. Oecologia 54:379-388

Searle DJ, Semeniuk V (1985) The natural sectors of the inner Rottnest Shelf coast adjoining the Swan Coastal Plain. J R Soc West Aust 67:116-136

Editorial responsibility: Otto Kinne (Editor-in-Chief), Oldendorf/Luhe, Germany
Shears NT, Babcock RC (2003) Marine reserves demonstrate top-down control of community structure on temperate reefs. Oecologia 132:131-142

Tuya F, Boyra A, Sanchez-Jerez P, Barbera C, Haroun RJ (2004) Relationships between rocky-reef fish assemblages, the sea urchin Diadema antillarum and macroalgae throughout the Canarian Archipelago. Mar Ecol Prog Ser 278:157-169

Vadas RL (1977) Preferential feeding: an optimization strategy in sea urchins? Ecol Monogr 47:337-371

Valentine JF, Heck KL Jr (1991) The role of sea urchin grazing in regulating subtropical seagrass meadows: evidence from field manipulations in the northern Gulf of Mexico. J Exp Mar Biol Ecol 154:215-230

Vanderklift MA (2002) Interactions between sea urchins and macroalgae in south-western Australia: testing general predictions in a local context. PhD thesis, University of Western Australia, Crawley

Vanderklift MA, Kendrick GA (2004) Variation in abundances of herbivorous invertebrates in temperate subtidal rocky reef habitats. Mar Freshw Res 55:93-103

Wernberg T, Kendrick GA, Phillips JC (2003) Regional differences in kelp-associated algal assemblages on temperate limestone reefs in south-western Australia. Divers Distrib 9:427-441

Wright JT, Steinberg PD (2001) Effect of variable recruitment and post-recruitment herbivory on local abundance of a marine alga. Ecology 82:2200-2215

Submitted: May 10, 2004; Accepted: May 26, 2005

Proofs received from author(s): August 4, 2005 